UDC 116: 316.3.+316.613.4

\author{
I. M. HOIAN ${ }^{1 *}$, V. P. BUDZ ${ }^{2 *}$ \\ ${ }^{1 *}$ Vasyl Stefanyk Precarpathian National University (Ivano-Frankivsk, Ukraine), e-mail ihor.hoian@pnu.edu.ua, \\ ORCID 0000-0003-2548-0488 \\ ${ }^{2 *}$ Ivan Franko National University of Lviv (Lviv, Ukraine), e-mail budzwolodymyr@gmail.com, ORCID 0000-0002-9245-7571
}

\title{
Emotions as Self-Organizational Factors of Anthropogenesis, Noogenesis and Sociogenesis
}

Purpose. The purpose is to prove the synchronicity of anthropogenesis, noogenesis and sociogenesis based on emotions, which are their self-organizational principles, as well as to reveal the synergistic essence of these processes. Theoretical basis. The study is based on the self-organizational paradigm, the theory of autopoiesis, labour theory, pananthropological concept, as well as on the concept of synergy of biological and mental phenomena. Originality. The concept of synchronicity of anthropogenesis, noogenesis and sociogenesis based on the emotions is substantiated. The concept of self-organizational emergence of emotions on the basis of hormones is developed. It is established that anthropogenesis is a process of anthropologisation of life based on biochemical reactions in the form of hormones and emotions, which are a synergy of genetic information, biochemical processes, instincts, and physiological phenomena. It was outlined that noogenesis has an emotional dimension, because emotions are the basis for self-organization of rationality, which begins at the level of emotional consciousness. The author shows the specifics of sociogenesis, which self-organizes based on social emotions, which in their turn "distinguish" a man from the sphere of natural existence based on the ability to control emotions. Conclusions. Emotions arise selforganizationally on the basis of hormones. They are self-organizational factors of anthropogenesis, noogenesis and sociogenesis based on the synergistic effect that arises through the combination of emotions and hormones at the biochemical level. The basic principle of anthropology is emotions that synchronize anthropogenesis, noogenesis and sociogenesis, which manifests themselves on the physical, mental, and spiritual levels. At the bodily level, emotions are expressed as biochemical and hormonal reactions. At the spiritual level emotions create the basis for the development of the mind, which originates as emotional consciousness. Emotions self-organize the process of anthropologisation of life, which is possible based on the synergy of human genome, biochemical, physiological phenomena and instincts. The concepts of synchronicity of anthropogenesis, noogenesis and sociogenesis and selforganizational emergence of emotions based on hormones initiate a promising direction of further research of the role of emotions in the processes of self-organization of social phenomena.

Keywords: hormones; emotions; anthropologisation of life; self-organization; anthropogenesis; noogenesis; sociogenesis

\section{Introduction}

There are a number of fundamental questions in the philosophy, which are actualizing with renewed vigour in the context of modern scientific achievements, especially in the field of neurosciences, biochemistry and genetics. Given the current development of these sciences, what are the basic principles that should be applied to solve the problem of the formation of man as an intelligent being and the formation of society? What "makes" human as biologic species a Human in the social sense? What are the basic factors in the process of anthropogenesis, noogenesis and sociogenesis (hereinafter - anthropo-, noo- and sociogenesis)? To answer these fundamental problems is to answer the question of substantial essence of human and society, as well as to create new methodological approaches to the development of the humanities. In such an aspect the subject of the research is relevant, as it provides a basis for the construction of theoretical and practical tool, which can be used to solve both the philosophical and urgent socio-political problems.

We propose new systematic view on the processes of anthropo-, noo-, and sociogenesis that are explained on the basis of the concept of their synchronicity we substantiated based on the 
accounting of the results achieved in neurosciences, biochemistry and genetics. Synchronicity of these processes rests on the fact that they are based on emotions, which is a simultaneous expression of biological, mental and rational phenomena that despite their distinct finite nature have common origins.

\section{Purpose}

The purpose of the study is to prove the synchronicity of anthropo-, noo- and sociogenesis based on emotions, which are their self-organizational principles, as well as to reveal the synergistic essence of these processes. Realization of this purpose involves solving the following tasks: a) to study the ontological base providing the synchronization of the processes of anthropo-, noo- and sociogenesis; b) to demonstrate the interrelation of biological and mental phenomena based on emotions, which are self-organizational expression of biochemical reactions at the hormone level and which influence the self-organization of the rationality and sociality; c) to single out the synergistic and autopoetic effect of emotions on the processes of anthropo-, nooand sociogenesis.

\section{Statement of basic materials}

\section{Approaches to the problem of human nature, his/her mind and society}

In philosophy, there are various methodological approaches to single out the fundamental principles of human development, his/her mind and society. For example, from the point of view

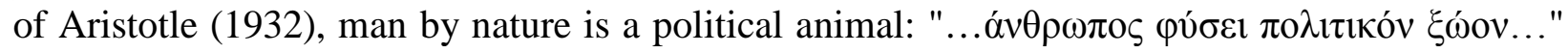
(p. 8), in addition, "all people have instilled desire to communicate in the state..." (authors' transl.) (Aristotle, 1932, p. 13). The philosopher's reflections are characterized by the apriority of policy, morality and rationality of human in accordance with the nature of things, because he believes that "...nature has given a man a weapon - mental ( $\varphi \rho$

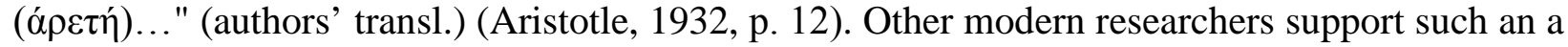
priori Aristotelian approach to the human nature. In particular, O. Bazaluk (2020) expresses the idea of moral apriority of man, because, in his opinion, "...existentials of arete reveal themselves as the first principle of anthropology, as the defining characteristics of the 'bottom' of human being and the primary basis of noogenesis" (p. 10), at the same time the existentials of arete are "intelligence, knowledge and techne" (Bazaluk, 2020, p. 15). However, policy, reason, morality and

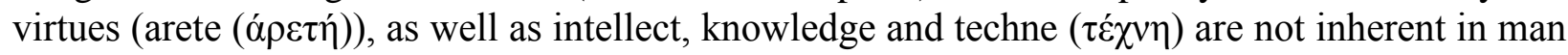
originally by the nature of things as the first principles. By the nature of things, man "possesses" only genetic apparatus, the corporeality, which creates the basis for the fact that he becomes ontologically present in existence as a living being. Policy, morality of a man, as well as intellect arise in the process of complex phenomena of life anthropologisation, which begins autopoetically at the biological level.

The autopoetic approach to the processes of anthropo-, noo- and sociogenesis is substantiated in the pananthropological concept of self-organization of man, social groups and social institutions (Budz, 2017). In the context of the pananthropological concept, "the self-organization of social existence is a pananthropological process, since only anthropological factors are involved in it..." (authors' transl.) (Budz, 2017, p. 14). Such an autopoetic and pananthropological approach within the social ontology can be one of the variants for solving the problems of anthropo-, noo- and sociogenesis.

Creative Commons Attribution 4.0 International doi: https://doi.org/10.15802/ampr.v0i19.236007 
The biological aspect of anthropo-, noo- and sociogenesis draws the attention of a number of researchers who emphasize the biological foundations of human development and reason (Butnariu \& Sarac, 2019; Varsha, Malavika, Vyshnavi, \& ShamsiyaRizwana, 2020). In particular, M. Butnariu and I. Sarac (2019) state that hormones related with the formation of emotions, behaviour and the way of thinking, play an important role in human behaviour (p. 1-3). Other researchers emphasize the role of biochemical foundations in the formation of a man, as "human body coordinates through chemical signals released by the brain. Chemical signals play a major role in bio-regulatory reactions responsible for emotions" (Varsha, Malavika, Vyshnavi, \& ShamsiyaRizwana, 2020, p. 26). Such a statement of the relationship between biochemical and mental processes can be an important theoretical basis for understanding the processes of anthropo-, noo- and sociogenesis.

In the context of the biochemical connection of emotions and hormones, human life in the community is not only a social but also a psychological and somatic need. Social isolation and alienation, and consequently feeling of loneliness cause many mental and somatic illnesses (Abdellaoui et al., 2019; Bellucci, 2020; J. Cacioppo, S. Cacioppo, Capitanio, \& Cole, 2015). In particular, according to some researchers, people "experience intense suffering when they perceive a lack of social connection" (Abdellaoui et al., 2019, p. 3853). In addition, "Loneliness is ... major factor of all-cause mortality" (Bellucci, 2020, p. 1). In this perspective, the idea is substantiated that "social isolation has been recognized as a major risk factor for morbidity and mortality" (J. Cacioppo, S. Cacioppo, Capitanio, \& Cole, 2015, p. 733). In this aspect, sociogenesis is based on human nature, which at the somatic and mental level "needs" sociality.

V. Khmil and T. Khmil (2015) draw attention to the moral level of sociogenesis, who, studying the anthropological basis of the state, note that "human society is based on a substantial form of morality, which is a manifestation of human freedom in choosing one's own value system" (authors' transl.) (p. 7). This approach is important for understanding the essence of anthropological processes. It is morality that "calls" to limit destructive emotions is the basis of sociogenesis. In this context, for example, T. Pavlova and V. Bobyl (2018) pay attention to the emotional side of the formation of human social behaviour and emphasize the negative emotions that affect it (p. 90).

A. Karas (2003) emphasizes an important role of social emotions in the processes of sociogenesis, who argues that subsidiarity and solidarity are the constituent principles of communities. He notes that "community members create... sociality by means of spreading solidarity and complementarity (subsidiarity)" (Karas, 2003, p. 23), and views civil society as a system of "links between individuals that create solidarity and subsidiarity norms of social reality..." (authors' transl.) (Karas, 2003, p. 426). But for solidarity and subsidiarity, the necessary foundations are such social emotions as trust, agreement, and tolerance.

Among the theories of anthropo-, socio- and noogenesis one can single out the theory of labour, which is defended by representatives of materialism. The latter emphasize the dominance of material factors and labour in the basis of the development of anthropo-, socio- and noogenesis. F. Engels (1950) sees the evolution of man in labour, because "...labour created man himself" (p. 7). The process of labour also affected the formation of society, as "the development of labour necessarily helped to bring the members of society closer together" (Engels, 1950, p. 10). However, in order for labour to be possible as a social phenomenon, the cooperation of people is necessary, and the latter does not arise, for example, without trust, responsibility, which are already social emotions. Therefore, the reason of possibility of the labour itself is the cooperation based on social emotions, which can be considered self-organizational principles of formation of 
socio- and anthropogenesis. In our opinion, social emotions are the constituent principles of life anthropologisation, they are the ones that "distinguish" man from the animal world. Life anthropologisation, as a primary link of anthropogenesis is performed on the basis of such social emotions as empathy, sympathy, sacrifice, solidarity. It is the social emotions and the ability to control them, not labour create the self-organizational basis for the development of man, his morality and civilization. If selfishness, xenophobia, and mistrust dominate at the intersubjective level of interactions, then sociality degrades. In this sense, emotions are the basis for the anthropologisation of life and the processes of anthropogenesis and sociogenesis. The latter unfolds at the level of morality and law, which are based on the ability of man to control emotions, which significantly distinguishes man from other species of living beings.

As we can see, there are different views on the initial principles of formation of man, his mind and society. We propose our own systematic view on the reasons of athropo-, noo- and sociogenesis, which is substantiated within the frameworks of this research.

\section{Paradoxes of anthropogenesis, noogenesis and sociogenesis and their solutions based on emotions}

Considering the problems of anthropo-, noo- and sociogenesis one should justify: 1) their historical sequence, or 2) to show that these are interdependent processes that are synchronous and synergistic. Considering the first aspect interrelation, one can assert that there is some historical formation pattern of 1) anthropogenesis, 2) noogenesis and 3) sociogenesis, which is based on biological nature of man. In biological sense one or another type of genesis is possible on the basis of the previous one and has the following historical sequence: 1) anthropogenesis, 2) noogenesis and 3) sociogenesis. In such a biological perspective, sociogenesis cannot begin earlier than noogenesis and anthropogenesis, because sociogenesis is the final stage of development of a man, who should behave rationally and morally in society.

In turn, noogenesis cannot begin earlier than anthropogenesis, because the appearance of mind requires the appearance of man. In this sense, there is the problem of classifying the human species in the biological aspect as Homo sapiens, because the biological appearance of man on the basis of evolution from the animal world does not guarantee that man instantly has a mind. Therefore, Homo sapiens is rather a good name for classifying the human species as both a biological and a social being. Homo is a biological genus of a number of primates, and the trait "sapiens" (from the Latin sapiens (sapio) - wise, intelligent, prudent) - is already a social quality of man. Wisdom, rationality are not only social, but also moral signs of a man. Therefore, it would be more appropriate to talk about the fact that in the process of anthropogenesis a genus Homo appears, which acquires the characteristics of sapiens on the basis of noogenesis and sociogenesis.

The emergence of society in the biological aspect historically was later than the emergence of man and his mind. Sociality is no longer a biological, but a moral and rational aspect of human existence. It "requires" a man to make a conscious, purposeful choice and a responsible attitude to norms and responsibilities. Thus, sociogenesis is impossible without noogenesis, because in order for a man to become social, it is necessary for him to first become intelligent and responsible. However, in order to make him intelligent and responsible, it is necessary for anthropogenesis to take place, i.e. the emergence of the very biological species of man from the sphere of existence and living nature is necessary. First, there must be an anthropologisation of life, which begins with genetic information and which through biochemical processes is selforganizationally transformed into emotions. 
In such aspect, we can say about the historical pattern of the genesis of man and society: 1) anthropogenesis; 2) noogenesis; 3) sociogenesis. At the same time, it is not expedient to comprehend these processes of life anthropologisation in such a linear historical sequence, because they are complementary, and therefore occur synchronously. The concept of synchronicity of anthropo-, noo-, and sociogenesis that we justify in the research makes it possible to solve paradoxical questions concerning the primacy of man, his mind and society. The paradox in solving these problems is based on the fact that if we talk about anthropogenesis as the emergence of the human species of living beings (Homo sapiens) in the biological sense, then historically anthropogenesis was the first. However, if we talk about anthropogenesis as the emergence of man in the social sense, then it is appropriate to interpret man in the context of his mind and social ties, because the presence of man in society requires conscious decisions and actions. Hence, anthropogenesis in the social sense is impossible without noogenesis and sociogenesis, and therefore, most likely, these processes in the social sense occur synchronously.

The synchronicity of these processes also follows from the fact that sociogenesis, as the emergence of society, is impossible without an existing man in the social sense, and man in the social dimension is impossible without mind (Bazaluk, 2019). Therefore, noogenesis is a necessary basis for sociogenesis. But rationality does not arise instantly, but requires social contact and imitation, that is, requires the existence of other intelligent people. However, people can become intelligent only by collective social efforts, and therefore sociogenesis is the necessary basis for the emergence of mind. In this case, sociogenesis precedes noogenesis. Hence, in order to solve these "paradoxes of primacy" it is advisable to talk about the synchronicity and synergy of anthropo-, noo- and sociogenesis.

However, what factor influences the synchronicity and synergy of anthropo-, noo- and sociogenesis? In our opinion, synchronization of these processes is possible on the basis of such anthropological phenomena as emotions. We believe that all the processes of the genesis of man, his mind and society (anthropo-, noo- and sociogenesis) combine emotions, in particular social emotions, which are their fundamental self-organizing factors. But how can emotions selforganize anthropo-, noo- and sociogenesis? Which mechanism is able to self-organize the athropologisation of life, i.e. development of man from the animal world, development of his mind and formation of society?

On the one hand, emotions are somewhat irrational, something that concerns instincts and physiological phenomena. Researchers have shown that "primordial emotions are the subjective element of the instincts which are the genetically programmed behaviour patterns which contrive homeostasis" (Denton, McKinley, Farrell, \& Egan, 2009, p. 500). Primary emotions are directly related to instincts, and the latter are irrational behavioural expressions of genetic information. However, emotions are not only a self-organizing expression of instincts, but also a selforganizing basis for the psyche formation. Emotions combine physical and mental phenomena, because there is a kind of emotion biochemistry, on the basis of which the physiology of the human body is reflected in emotions. In general, emotions are based on the biochemical processes of the human body, because, for example, "...emotion is defined as the complex collection of chemical and neural responses initiated by brain which have physical and mental components..." (Varsha, Malavika, Vyshnavi, \& ShamsiyaRizwana, 2020, p. 26). Emotions really synergistically combine somatic, mental and spiritual phenomena, i.e. they are a self-organizing consequence of the synthesis of genetic information, biochemical processes, instincts and physiological phenomena. This causes the synchronization of anthropo-, noo- and sociogenesis. To confirm our rea- 
soning about the concept of self-organizational emergence of emotions and the concept of synchronization of anthropo-, noo- and sociogenesis based on them, we quote a group of researchers who show that "... there is a clear correspondence between the mental experiences and their bodily basis that also pertains to the underlying neural activation patterns in the bodily domain" (Nummenmaa, Hari, Hietanen, \& Glerean, 2018, p. 9199). That is, there is a direct synergy between the body, brain and emotions based on biochemical reactions, because "human brain ... transmits information through chemicals.... These chemicals let the organs communicate with each other and express the emotions" (Varsha, Malavika, Vyshnavi, \& ShamsiyaRizwana, 2020, p. 26). In this aspect emotions arise self-organizationally on the basis of biochemical reactions and "combine" corporeality, psyche and rationality. On the basis of such a synergistic understanding of the nature of emotions, the paradoxes of anthropo-, noo- and sociogenesis can be solved, in particular, through the concept of their synchronization based on emotions, which, firstly, arise self-organizationally, and secondly, are their self-organizational bases.

\section{Emotions as a self-organizing basis for the emergence of rationality}

Emotions arise not only self-organizationally based on the biochemical processes, in particular, hormones, but are also a self-organizational basis for the emergence of primary rational intentions and meanings that are associated with bodily well-being and primordial mental experiences. According to the researchers, "emotions are one the most central and pervasive aspects of human experience" (Varsha, Malavika, Vyshnavi, \& ShamsiyaRizwana, 2020, p. 26). Emotions according to their genesis arise self-organizationally in relation to corporeality, and, hence, human body and its conditions "take" an important part in the processes of noogenesis. Researchers believe that "bodily states are fundamental to emotions' emergence and are believed to constitute the first step in the chain of events that culminate in emotional awareness" (Novembre, Zanon, Morrison, \& Ambron, 2019, p. 1). In this aspect the reflections on the fact that "the brain is the place where multiple chemical reactions occur that change our emotions, behavior, and even the way we think" are important (Butnariu \& Sarac, 2019, p. 2). Initially, emotions in the process of anthropogenesis are complex biochemical reactions that occur on the basis of hormones secreted in the brain and internal organs. In particular, "hormones that affect brain activity are chemicals ... As they circulate through the bloodstream, the hormones ...exercise their control over metabolism... mood... Any hormonal imbalance is followed either by a physical affection or by an emotional manifestation" (Butnariu \& Sarac, 2019, p. 2). That is, originally emotions are based on the biological basis and self-organizationally related to hormonal processes, since "almost all hormones are involved in emotions..." (Butnariu \& Sarac, 2019, p. 2). However, the synergistic relationship of hormones and emotions cannot be one-sided, and therefore emotions can also influence the occurrence of biochemical reactions, i.e. "every emotion triggers hormonal secretions..." (Butnariu \& Sarac, 2019, p. 1). Herewith, "emotions are complex chemical reactions in nervous system characterized by neurophysiologic changes associated with thoughts and behavioral responses" (Varsha, Malavika, Vyshnavi, \& ShamsiyaRizwana, 2020, p. 26).

In general, according to the researchers, "hormones start the emotions and the intelligence" (Butnariu \& Sarac, 2019, p. 2), in particular, emotions "provide" original senses, thoughts and meanings to the mind. Emotional consciousness is the primary self-organizing form of functioning of consciousness in general, because it dominates in the early stages of human intelligence. The reflection that "...emotion is often considered as an essential building block of consciousness" is important (Nummenmaa, Hari, Hietanen, \& Glerean, 2018, p. 9198). At the same time, 
for example, it should be taken into account that "aesthetic perception and judgement are not merely cognitive processes, but also involve feelings" (Schindler et al., 2017, p. 1). We can see the similar results in another research, which assert that "... emotions amplify different moral judgements, based on the emotion's core appraisals" (Horberg, Oveis, \& Keltner, 2011, p. 237). In this aspect "the ethical emotions...can affect, through the cognitive aspect of the emotional process, the decision-making process of people..." (Pavlova \& Bobyl, 2018, p. 84). Man really "experiences a decision-making process at the emotional level" (Hoian, 2019, p. 73), in particular, "some emotions, such as fear, are crucial for decision-making" (Hoian, 2019, p. 71). Here we see that aesthetic, ethical judgements are correlated with emotions, and therefore it is not improbable that emotions also affect other types of judgements. The influence of emotions on judgement indicates a direct connection between mental and rational and an indirect connection between the body and the mind, because the body, including the brain and nervous system, is a self-organizing biochemical source of emotions.

\section{Synchronization of anthropological processes based on emotions}

As we can see, noogenesis (the process of formation of intellect and consciousness) is quite possible on an irrational basis represented by emotions, because they are the components of biological and mental processes, which indicates their synergistic nature. Therefore, the synchronization of anthropo-, noo-, and sociogenesis is possible on the basis of biochemical reactions, which are embodied in emotions. In such an aspect emotions are the basis of formation of consciousness and all social phenomena.

Although anthropogenesis has some historical superiority in the fact that it involves the human body, which is "endowed" with genetic information and life, but together with it the processes of noogenesis and sociogenesis based on emotions begin synchronously. These processes cannot be caused by genetic information alone. If anthropogenesis in the biological sense begins as the anthropologisation of life, because it is initially possible only based on genetic information, then genetic information and the human genome are not yet a guarantee of rationality and sociality. In order for genetic information (as a biological phenomenon) to act at the level of the functioning of the human mind and society, it would have to transform itself into some rational and social forms. Such primary rational and social forms, in our opinion, are emotions, as the latter influence the formation of emotional consciousness and interpersonal relationships.

Emotions arise self-organizationally on the basis of biochemical phenomena, combining, on the one hand, genetic and biological, and on the other - mental and rational. The biochemistry of emotions involves the synchronous unity of the somatic, mental and rational. Genetic information, developing and changing or undergoing mutations, becomes the basis for selforganizational formation of emotional states in man at the biochemical level. Some primary emotions that arise on a biochemical basis are later transformed into social emotions, becoming the basis for noogenesis and sociogenesis. In this aspect, "emotions motivate empathic and moral behavior..." (Varsha, Malavika, Vyshnavi, \& ShamsiyaRizwana, 2020, p. 26). In this vision, emotions are the basis for self-organization of moral and aesthetic behaviour. In particular, T. Pavlova and V. Bobyl (2018), analysing negative emotions, indicate that they have "constructive and destructive effect on person's behaviour" (p. 90).

All emotions have their synchronous biochemical and physiological expression at the bodily level as manifestations of bodily reactions - activation of the brain, facial expressions, muscle tension, skin reactions, heart rate, and blood pressure. Thus, "expression of every emotion in 
human beings is the result of brain signaling" (Varsha, Malavika, Vyshnavi, \& ShamsiyaRizwana, 2020, p. 27). Emotions are also accompanied by biochemical reactions with the release of various hormones and other chemicals (including neurotransmitters stimulating the work of different parts of the brain), changes in blood chemical composition. Emotions directly affect anthropogenesis and indirectly noogenesis and sociogenesis through the production of hormones that are chemicals. According to the researchers, "...hormones are chemicals...released into the bloodstream to influence physical, physiological, behavioral changes..." (Butnariu \& Sarac, 2019, p. 1), i.e. "invest with the function of 'managers'; hormones control fundamental impulses and emotions..." (Butnariu \& Sarac, 2019, p. 2). Such considerations indicate the selforganization of emotions occurrence from the biochemical basis and the nervous system.

The relationship between emotions and hormones (which also act as neurotransmitters), and in general the relationship between emotions and biochemical processes, indicates a direct synergy and synchronization of physical and mental, and on this basis also rational. Emotions directly affect the activation of the brain, the state of the immune system, and health in general, i.e. "...the intensity of emotions reverts to physical health" (Butnariu \& Sarac, 2019, p. 1). In addition, emotions can be the basis for the formation of consciousness (Novembre, Zanon, Morrison, \& Ambron, 2019; Nummenmaa, Hari, Hietanen, \& Glerean, 2018; Schindler et al., 2017). Hence, emotions are the basis for synchronizing the processes of anthropo-, noo- and sociogenesis, because they are involved in these three processes simultaneously.

\section{Self-organizational role of emotions in sociogenesis}

Genetically, man is not "programmed" for sociality or asociality. However, genetic information, mediated through emotions, can be the basis of sociogenesis, although it does not directly affect the degree of social integration or alienation. The appearance of emotions is biochemical, but their manifestation by man is associated with choice, control and has a moral meaning. Man is able to control his emotions, which is why emotions, having a self-organizing biochemical origin, already acquire a social and moral character. As a result of moral control, most emotions become social and acquire the status of self-organizing social factors. Only man, of all other living beings, is able to control his emotions on the basis of moral and legal norms, and therefore he is indirectly able to control genetics, body (bodily desires), leading, for example, an ascetic lifestyle, neglect instincts and act sacrificially and altruistically. The true essence of man (in the social sense) lies in his morality, in the ability for interpersonal interaction on the basis of rules and norms that correct the expression of desires, emotions, feelings. The human dimension of sociogenesis lies in its unfolding on the basis of controlled emotions.

Neither "genes of sociality" nor genes of any type of behaviour are embedded in the human genome. It does not contain socio-behavioural (mental), but only biological information. The latter directly affects only homeostasis, instinctive behaviour and expression of primordial emotions. But the essence of man is based precisely on the fact that man is able to recognize and control emotions. It is from this human ability that anthropogenesis begins in the social aspect, as well as noogenesis (emotion recognition) and sociogenesis (emotion control).

The human genome cannot directly contain the mental, because mentality is a social feature of a man. So is culture, sign systems cannot precede human physiology and genetics. Although, for example, L. Osadcha (2015) proposes to consider physiological mutations of the human body as a consequence of the use of signs and enculturation, i.e. "creation of collectively significant symbols... causes a change in physiology: the semantic factor triggers the evolution of physio- 
logical parameters of man. The price of culturedness affected human physiology" (authors' transl.) (p. 32). According to L. Osadcha (2015), symbolic, sign, and in general cultural actions arose earlier, for example, from bipedalism, because the latter is a consequence of human enculturation: "bipedalism is physiological mutation, which man paid for the transition to paradoxical, symbolic, and therefore cultural behaviour" (p. 33). It follows that noogenesis, sociogenesis and culturogenesis began earlier than anthropogenesis, but this view is debatable. Mentality is determined not by genetic factors, but by social ones.

On the other hand, mentality cannot directly affect genetics, except indirectly, through emotions, which, in turn, can act to change a man's hormonal balance. It is not mentality, not ideology, not worldview, not sign systems that influence genetics, but emotions that are related to genetics at the biochemical level (Kalmykova, Kharchenko, Volzhentseva, Kalmykov, \& Mysan, 2020). In order for any sign systems to affect genetics, they must be transformed into emotions. Only in this way, for example, ideology, philosophy, religion can influence genetics and the degree of social unity or differentiation.

The formation of social ties is not under the influence of genetics, but on the basis of social emotions, i.e. "at the personal intersubjective level, people interact primarily on the basis of emotions and feelings" (Hoian \& Budz, 2020, p. 78). In general, "any 'possible' social world unfolds as an ontology of social feelings that 'solidify' or 'differentiate' the community" (Budz, 2017, p. 168). Thus, emotions are the self-organizing foundations of sociality. The human genome is only indirectly connected with sociality through anthropological mechanisms, emotions, on the basis of which anthropogenesis takes place. At the level of genetic information, the human body only partially "dictates" a person's way of life, which consists in work, survival, procreation, because man is a living being. But interpersonal social behaviour is not genetically determined, but emotionally, the actual social connection is possible because people control their emotions based on the moral and legal norms.

\section{Originality}

The study substantiates the concept of synchronicity of anthropo-, noo- and sociogenesis based on emotions. Emotions are the basic principle of anthropology, and at the same time anthropo-, noo- and sociogenesis, because they synchronize these processes. Emotions ensure the evolution of man into an intelligent and social being, because they synergistically combine body, mind and spirit (mind and intellect) at the biochemical level. The article develops the concept of selforganizational appearance of emotions based on hormones. Emotions are the result of selforganizational synthesis of genetic information, biochemical processes in the form of hormones, physiological phenomena and instincts, and this causes the synchronization of anthropo-, noo- and sociogenesis. It is proved that on the basis of emotions it is carried out: 1) anthropogenesis, i.e. anthropologisation of life through the biochemical connection of hormones and emotions that becomes the basis for the emergence of the primary foundations of mind and consciousness, which "distinguish" man from other species. Emotions are also the basis for: 2) noogenesis, because they become the basis for the emergence of consciousness (including emotional), because man is able to recognize emotions; and 3) sociogenesis, because they develop the social essence of man based on the fact that man is able to control emotions. It is emotions that at the biochemical level create a self-organizing basis on the one hand for: a) activation and development of the brain, and on its basis - the mind and intellect (i.e. emotions "initiate" noogenesis); and b) development of interpersonal relationships and the social nature of man (i.e. social emotions "start" sociogenesis). 


\section{Conclusions}

Emotions are self-organizing factors of anthropo-, noo- and sociogenesis based on the synergistic effect that they create through their combination with hormones at the biochemical level. The basic principle of anthropology is emotions, because they synchronize anthropo-, noo- and sociogenesis. The primary consequence of the anthropologisation of life is emotions that arise self-organizationally and are a synergy of genetic information, biochemical processes, physiological phenomena and instincts. On the basis of emotions, anthropogenesis is self-organized, which unfolds as a phenomenon of anthropologisation of life through biochemical reactions. Self-organization of noogenesis occurs based on the formation of emotional consciousness, which affects the process of formulating primary judgements. Sociogenesis is possible through the development of emotional interpersonal connections that self-organize on social emotions.

The concepts of synchronicity of anthropo-, noo- and sociogenesis and self-organizational emergence of emotions based on hormones, which are substantiated in the study, can be a methodological basis for interpreting the essential features of human development, mind and society in humanitarian research. A promising area of further research of emotions in the context of anthropo-, noo- and sociogenesis is to clarify the role of emotions in the processes of selforganization of morality, law, history, economics, language and other social phenomena.

\section{REFERENCES}

Abdellaoui, A., Sanchez-Roige, S., Sealock, J., Treur, J. L., Dennis, J., Fontanillas, P., ... Boomsma, D. I. (2019). Phenome-wide investigation of health outcomes associated with genetic predisposition to loneliness. Human Molecular Genetics, 28(22), 3853-3865. DOI: https://doi.org/10.1093/hmg/ddz219 (in English)

Aristotle. (1932). Politics (H. Rackham, Trans.). London: William Heinemann LTD. Retrieved from https://archive.org/details/politicsrackh00arisuoft (in English and in Ancient Greek)

Bazaluk, O. (2019). The Transformation of a Cultural Ideal in the Theories of Education According to Plato's Line. Studia Warmińskie, 56, 95-104. DOI: https://doi.org/10.31648/sw.4598 (in English)

Bazaluk, O. A. (2020). The Anthropologization of Dasein-Psyche's Being by Methods of Neurophilosophy. Anthropological Measurements of Philosophical Research, 18, 7-19. DOI: https://doi.org/10.15802/ ampr.v0i18.221297 (in English)

Bellucci, G. (2020). Positive attitudes and negative expectations in lonely individuals. Scientific Reports, $10,18595$. DOI: https://doi.org/10.1038/s41598-020-75712-3 (in English)

Budz, V. P. (2017). Self-Organisation of Social Groups and Social Institutes as a Pan-Anthropological Process. In Self-Organisation of Public Reality in the Context of its Anthropological Principles and Axiological Factors (Vol. 4). Ivano-Frankivsk: Vasyl Stefanyk Precarpathian National University. (in Ukrainian)

Butnariu, M., \& Sarac, I. (2019). Biochemistry of Hormones that Influences Feelings. Annals of Pharmacovigilance \& Drug Safety, 1(1), 1001. (in English)

Cacioppo, J. T., Cacioppo, S., Capitanio, J. P., \& Cole, S. W. (2015). The Neuroendocrinology of Social Isolation. Annual Review of Psychology, 66(1), 733-767. DOI: https://doi.org/10.1146/annurev-psych-010814-015240 (in English)

Denton, D. A., McKinley, M. J., Farrell, M., \& Egan, G. F. (2009). The role of primordial emotions in the evolutionary origin of consciousness. Consciousness and Cognition, 18(2), 500-514. DOI: https://doi.org/ 10.1016/j.concog.2008.06.009 (in English)

Engels, F. (1950). The Part played by Labour in the Transition from Ape to Man. New York: International Publishers. Retrieved from https://stars.library.ucf.edu/prism/610 (in English)

Hoian, I. M. (2019). Axiological Aspects of Moral and Legal Decision-Making. Anthropological Measurements of Philosophical Research, 16, 66-77. DOI: https://doi.org/10.15802/ampr.v0i16.187572 (in English)

Hoian, I. M., \& Budz, V. P. (2020). Anthropological and Axiological Dimensions of Social Expectations and their Influence on Society's Self-Organization. Anthropological Measurements of Philosophical Research, 18, 76-86. DOI: https://doi.org/10.15802/ampr.v0i18.221379 (in English) 
Horberg, E. J., Oveis, C., \& Keltner, D. (2011). Emotions as Moral Amplifiers: An Appraisal Tendency Approach to the Influences of Distinct Emotions upon Moral Judgment. Emotion Review, 3(3), 237-244. DOI: https://doi.org/10.1177/1754073911402384 (in English)

Kalmykova, L., Kharchenko, N., Volzhentseva, I., Kalmykov, H., \& Mysan, I. (2020). Actualization of the Internal Speech Problems in Psycholinguistics of Communication: The Results of a Systematic Review and MetaAnalysis. Psycholinguistics, 28(1), 83-148. DOI: https://doi.org/10.31470/2309-1797-2020-28-1-83-148 (in Ukrainian)

Karas, A. F. (2003). Philosophy of civil society in classical theories and non-classical interpretations: Monograph. Kyiv, Lviv: Ivan Franko Lviv National University Publishing Center. (in Ukrainian)

Khmil, V. V., \& Khmil, T. V. (2015). Anthropological aspect of the nature of the state. Anthropological Measurements of Philosophical Research, 7, 7-15. DOI: https://doi.org/10.15802/ampr2015/43374 (in Ukrainian)

Novembre, G., Zanon, M., Morrison, I., \& Ambron, E. (2019). Bodily sensations in social scenarios: Where in the body? PLoS ONE, 14(6), e0206270. DOI: https://doi.org/10.1371/journal.pone.0206270 (in English)

Nummenmaa, L., Hari, R., Hietanen, J. K., \& Glerean, E. (2018). Maps of subjective feelings. Proceedings of the National Academy of Sciences, 115(37), 9198-9203. DOI: https://doi.org/10.1073/pnas.1807390115 (in English)

Osadcha, L. V. (2015). Genetic Determinants of Mentality. Anthropological Measurements of Philosophical Research, 8, 29-37. DOI: https://doi.org/10.15802/ampr2015/55722 (in Ukrainian)

Pavlova, T. S., \& Bobyl, V. V. (2018). The Phenomenon of Negative Emotions in the Social Existence of Human. Anthropological Measurements of Philosophical Research, 14, 84-93. DOI: https://doi.org/10.15802/ ampr.v0i14.115314 (in English)

Schindler, I., Hosoya, G., Menninghaus, W., Beermann, U., Wagner, V., Eid, M., \& Scherer, K. R. (2017). Measuring aesthetic emotions: A review of the literature and a new assessment tool. PLoS ONE, 12(6), e0178899. DOI: https://doi.org/10.1371/journal.pone.0178899 (in English)

Varsha, N., Malavika, B., Vyshnavi, V. R., \& ShamsiyaRizwana. (2020). Chemistry of Emotions - A Review. International Journal for Modern Trends in Science and Technology, 6(10), 26-30. DOI: https://doi.org/ 10.46501/IJMTST061005 (in English)

\section{LIST OF REFERENCE LINKS}

Abdellaoui A., Sanchez-Roige S., Sealock J., Treur J. L., Dennis J., Fontanillas P., ... Boomsma D. I. Phenomewide investigation of health outcomes associated with genetic predisposition to loneliness. Human Molecular Genetics. 2019. Vol. 28. Iss. 22. P. 3853-3865. DOI: https://doi.org/10.1093/hmg/ddz219

Aristotle. Politics / trans. by H. Rackham. London : William Heinemann LTD, 1932. xxiii, 683 p. URL: https://archive.org/details/politicsrackh00arisuoft

Bazaluk O. The Transformation of a Cultural Ideal in the Theories of Education According to Plato's Line. Studia Warmińskie. 2019. Vol. 56. P. 95-104. DOI: https://doi.org/10.31648/sw.4598 (in English)

Bazaluk O. A. The Anthropologization of Dasein-Psyche’s Being by Methods of Neurophilosophy. Anthropological Measurements of Philosophical Research. 2020. No. 18. P.7-19. DOI: https://doi.org/10.15802/ ampr.v0i18.221297

Bellucci G. Positive attitudes and negative expectations in lonely individuals. Scientific Reports. 2020. Vol. 10. 9 p. DOI: https://doi.org/10.1038/s41598-020-75712-3

Будз В. П. Самоорганізація суспільної дійсності в контексті ї̈ антропологічних засад та аксіологічних чинників: у 5 т. : монографія. Т. 4 : Самоорганізація суспільних груп та соціальних інститутів як панантропологічний процес. Івано-Франківськ : Прикарпат. нац. ун-т ім. В. Стефаника, 2017. 481 с.

Butnariu M., Sarac I. Biochemistry of Hormones that Influences Feelings. Annals of Pharmacovigilance \& Drug Safety. 2019. Vol. 1. Iss. 1.5 p.

Cacioppo J. T., Cacioppo S., Capitanio J. P., Cole S. W. The Neuroendocrinology of Social Isolation. Annual Review of Psychology. 2015. Vol. 66. Iss. 1. P. 733-767. DOI: https://doi.org/10.1146/annurev-psych010814-015240

Denton D. A., McKinley M. J., Farrell M., Egan G. F. The role of primordial emotions in the evolutionary origin of consciousness. Consciousness and Cognition. 2009. Vol. 18. Iss. 2. P. 500-514. DOI: https://doi.org/ 10.1016/j.concog.2008.06.009

Engels F. The Part played by Labour in the Transition from Ape to Man. New York : International Publishers, 1950. 22 p. URL: https://stars.library.ucf.edu/prism/610

Creative Commons Attribution 4.0 International

doi: https://doi.org/10.15802/ampr.v0i19.236007 
Hoian I. M. Axiological Aspects of Moral and Legal Decision-Making. Anthropological Measurements of Philosophical Research. 2019. No. 16. P. 66-77. DOI: https://doi.org/10.15802/ampr.v0i16.187572

Hoian I. M., Budz V. P. Anthropological and Axiological Dimensions of Social Expectations and their Influence on Society's Self-Organization. Anthropological Measurements of Philosophical Research. 2020. No. 18. P. 76-86. DOI: https://doi.org/10.15802/ampr.v0i18.221379

Horberg E. J., Oveis C., Keltner D. Emotions as Moral Amplifiers: An Appraisal Tendency Approach to the Influences of Distinct Emotions upon Moral Judgment. Emotion Review. 2011. Vol. 3. No. 3. P. 237-244. DOI: https://doi.org/10.1177/1754073911402384

Kalmykova L., Kharchenko N., Volzhentseva I., Kalmykov H., Mysan I. Actualization of the Internal Speech Problems in Psycholinguistics of Communication: The Results of a Systematic Review and Meta-Analysis. Psycholinguistics. 2020. Vol. 28. No. 1. P. 83-148. DOI: https://doi.org/10.31470/2309-1797-2020-28-183-148

Карась А. Ф. Філософія громадянського суспільства в класичних теоріях і некласичних інтерпретачіях : монографія. Київ, Львів : Видавничий центр ЛНУ імені Івана Франка, 2003. 520 с.

Khmil V. V., Khmil T. V. Anthropological aspect of the nature of the state. Anthropological Measurements of Philosophical Research. 2015. No. 7. P. 7-15. DOI: https://doi.org/10.15802/ampr2015/43374

Novembre G., Zanon M., Morrison I., Ambron E. Bodily sensations in social scenarios: Where in the body? PLoS ONE. 2019. Vol. 14. Iss. 6. 21 p. DOI: https://doi.org/10.1371/journal.pone.0206270

Nummenmaa L., Hari R., Hietanen J. K., Glerean E. Maps of subjective feelings. Proceedings of the National Academy of Sciences. 2018. Vol. 115. Iss. 37. P. 9198-9203. DOI: https://doi.org/10.1073/pnas.1807390115

Osadcha L. V. Genetic Determinants of Mentality. Anthropological Measurements of Philosophical Research. 2015. No. 8. P. 29-37. DOI: https://doi.org/10.15802/ampr2015/55722

Pavlova T. S., Bobyl V. V. The Phenomenon of Negative Emotions in the Social Existence of Human. Anthropological Measurements of Philosophical Research. 2018. No. 14. P. 84-93. DOI: https://doi.org/ 10.15802/ampr.v0i14.115314

Schindler I., Hosoya G., Menninghaus W., Beermann U., Wagner V., Eid M., Scherer K. R. Measuring aesthetic emotions: A review of the literature and a new assessment tool. PLoS ONE. 2017. Vol. 12. Iss. 6. 45 p. DOI: https://doi.org/10.1371/journal.pone.0178899

Varsha N., Malavika B., Vyshnavi V. R., ShamsiyaRizwana. Chemistry of Emotions - A Review. International Journal for Modern Trends in Science and Technology. 2020. Vol. 6. Iss. 10. P. 26-30. DOI: https://doi.org/ 10.46501/IJMTST061005

\section{І. М. ГОЯН ${ }^{1^{*}}$ В. П. БУДЗ $3^{2 *}$}

1* Прикарпатський національний університет імені Василя Стефаника (Івано-Франківськ, Україна), ел. пошта ihor.hoian@pnu.edu.ua, ORCID 0000-0003-2548-0488

2* Львівський національний університет імені Івана Франка (Львів, Україна), ел. пошта budzwolodymyr@gmail.com, ORCID 0000-0002-9245-7571

\section{Емоції як самоорганізаційні фактори антропогенезу, ноогенезу та соціогенезу}

Мета. Довести синхронність антропогенезу, ноогенезу та соціогенезу на основі емоцій, які $\epsilon$ їх самоорганізаційними принципами, та розкрити синергійну сутність цих процесів. Теоретичний базис. Дослідження грунтується на самоорганізаційній парадигмі, теорії автопоезису, трудовій теорії, панантропологічній концепції, а також концепції синергії біологічних і психічних явищ. Наукова новизна. Обгрунтовано концепиію синхронності антропогенезу, ноогенезу та соиіогенезу, яка заснована на емоціях. Розроблено концепиію самоорганізаціийного виникнення емоцій на основі гормонів. Встановлено, що антропогенез - це процес антропологізації життя на базі біохімічних реакцій у формі гормонів та емоцій, які є синергією генетичної інформації, біохімічних процесів, інстинктів і фізіологічних явищ. Окреслено, що ноогенез має емоційний вимір, оскільки емоції перебувають в основі самоорганізації раціональності, яка започатковується на рівні емоційної свідомості. Показано специфіку соціогенезу, який самоорганізовується на підставі соціальних емоцій, що "виділяють" людину зі сфери природного буття на основі вміння контролювати 
емоції. Висновки. Емоиії виникають самоорганізаиійно на основі гормонів. Вони $є$ самоорганізаиійними факторами антропогенезу, ноогенезу та соиіогенезу на основі синергійного ефекту, який виникає через поєднання емоцій і гормонів на біохімічному рівні. Вихідним принципом антропології є емоції, які синхронізують антропогенез, ноогенез і соціогенез, що проявляються на тілесному, психічному та духовному рівнях. На тілесному рівні емоції виражаються як біохімічні та гормональні реакції. На духовному рівні емоції створюють підгрунтя для розвитку розуму, який виникає як емоційна свідомість. Емоції самоорганізовують процес антропологізації життя, який можливий на засадах синергії людського геному, біохімічних, фізіологічних явищ та інстинктів. Концепції синхронності антропогенезу, ноогенезу, соціогенезу та самоорганізаційного виникнення емоцій на основі гормонів започатковують перспективний напрям подальших досліджень ролі емоцій у процесах самоорганізації соціальних явищ.

Ключові слова: гормони; емоції; антропологізація життя; самоорганізація; антропогенез; ноогенез; соціогенез

Received: 11.01.2021

Accepted: 25.05.2021 